Gender, age, attendance at a place of worship and young people's attitudes towards the Bible

\author{
Dr R. J. K. Freathy \\ Research and Teaching Fellow \\ School of Education and Lifelong Learning \\ University of Exeter \\ St. Luke's Campus \\ Heavitree Road \\ Exeter \\ EX1 2LU
}




\title{
Gender, age, attendance at a place of worship and young people's attitudes towards the Bible
}

\begin{abstract}
This article discusses the outcomes of a questionnaire survey which sought to ascertain the attitudes of young people towards the Bible. One thousand and sixty-six pupils from Years 6, 9 and 12 in nine English schools participated. The young people's attitudes are discussed in relation to gender, age and attendance at a place of worship. The research team found that being female, in Year 6 and attending a place of worship very often are factors associated with the most positive attitudes towards the Bible, while being male, in Year 9 and never attending a place of worship are associated with the least positive attitudes. The article also discusses the difficulty of explaining individual correlations regarding age and gender.
\end{abstract}




\section{Age, gender, attendance at a place of worship and young people's attitudes towards the Bible}

\section{Introduction}

In the first two phases of the Biblos Project, new curriculum materials about the Bible were trialled with pupils from key stages (KS) one to four in schools in Cornwall, Devon, Ealing (London) and Lancashire (Copley, 1998 and Copley et al, 2001). These materials were subsequently published commercially (Copley, 2002; Copley et al, 2002; Savini, 2002; Walshe, 2002; Bowness, 2005; Brimicombe, 2005; and Lane, 2005). A survey of attitudes towards the Bible was also undertaken with $722 \mathrm{KS}$ four pupils in phase two of the project. When asked about their initial reaction to studying biblical narratives as part of the project, $30 \%$ of the pupils said they were not keen, $27 \%$ said they were uncertain and $26 \%$ said they were indifferent. (Copley et al, 2001: 28). Moreover, 36\% said they thought the Bible was not relevant for people today, $25 \%$ asserted it was relevant for some people, but not others and 5\% said they were unsure (ibid: 33). On the basis of these indicators, the project team questioned whether the unpopularity of the Bible in Religious Education (RE) is due to external factors rather than the way it is presented (ibid: 41). Thus, the third phase of the project sought to find out what shapes young people's attitudes towards the Bible (Copley et al, 2004). 
In his review of RE research, Francis (1996: 108-12) noted a number of major studies into children's attitudes. Firstly, Hyde (1965) developed an instrument to measure pupils' attitudes towards God, the Bible, religion, the institutional church, the local church and churchgoing. Secondly, Cox (1967) sought to gauge the opinions of grammar school pupils on: (i) the existence of God; (ii) Jesus; (iii) life after death; (iv) the Bible; (v) the church; (vi) RE; (vii) personal religious behaviour; and (viii) moral behaviours. In 1970, he replicated the study to look at changes in attitudes towards RE and the Bible (Cox, 1971). Thirdly, Alves (1968) reported findings regarding pupils': (i) knowledge of the New Testament; (ii) understanding of New Testament quotations; (iii) beliefs and attitudes about Jesus, the bible and the church; (iv) moral choices; and (v) religious identity and practice. Fourthly, Francis (1996: 121) himself developed and improved this area of $\mathrm{RE}$ research by conducting approximately eighty published studies into children's attitudes towards Christianity by 1996. Francis (1984:47) defined attitude as an evaluative predisposition to a positive or negative response of an affective nature. Thus, it is possible to hold traditional beliefs about God, while at the same time holding unfavourable attitudes towards him.

Francis (1984: 46) conducted his research using a 24-item (five point) Likert Scale which addressed the features that he believed characterise a pupil's concept of Christianity: God, Jesus, the Bible, 
prayer, the Church and Christian instruction and worship in schools. The same instrument was administered to all pupils in Years 7-11 in two comprehensive schools in Essex and Suffolk every four years from 1974 to 2002. The Likert Scale items pertaining to the Bible were 'I find it boring to listen to the Bible' and 'I think the Bible is out of date' (1989a: 78). Francis (2000:166) constructed a profile of the way in which young people's attitudes have changed. In $1974,33 \%$ of secondary school pupils agreed with the statement 'I find it boring to listen to the Bible', but the proportion increased in almost every quadrennial replication until 1994 (34\%, 40\%, 49\%, $48 \%$ and $51 \%$ ). Moreover, in terms of the frequency with which the Bible is read, Francis (2000: 170) noted, in a different study, that only 5\% of English and Welsh 13-15 year olds read it regularly and two out of three never read it. Furthermore, when he administered his Centymca Attitude Inventory to 33,982 young people from 163 English and Welsh schools, Francis (2001) reported that 31\% agreed strongly or agreed, $41 \%$ were not certain and $28 \%$ disagreed strongly or disagreed, with the statement 'The Bible seems irrelevant to life today' (2001: 36-8). According to Francis (ibid: 39), there is a generation of young people who wish to retain the notion of being Christian, but who feel neutral about the Bible.

\section{Gender}

The first key influence upon children's attitudes towards the Bible, which the Biblos Project research team investigated, was gender. 
Davies (2004) has cited numerous studies that demonstrate that females have more positive attitudes towards religion than males (Hyde, 1965; Hyde, 1990; Turner, 1970; Greer, 1972b; and Francis, 1987). Greeley (1992) and Roberts (1996) have also reported the greater religiosity of females over males. Furthermore, Francis (1986b) has noted almost unequivocal evidence during the past 40 years to suggest that females have a more positive attitude to Christianity than males (Glassey, 1943; Garrity, 1960; Povall, 1971; and Kay, 1981). In his own work, Francis (1989a: 79) stated that females score more highly (i.e. more positively) than males on all of the 24 items in his scale of attitudes towards Christianity. Males were also twice as likely as females to dismiss the Bible as oldfashioned. Meanwhile, a third of the males (34\%) felt that the Bible is out of date compared with a sixth of the females (17\%). This conclusion was supported by a later study by Francis and Greer (1999a: 177) in which they surveyed pupils from Years 9, 10, 11 and 12 from twelve Catholic (1,034 pupils) and twelve Protestant (1,095 pupils) grammar schools in Northern Ireland. Finally, in his survey of 13-15 year olds, Francis (2001: 100-1) noted that females held a higher level of religious belief than males and were more likely to express belief in God, belief that Jesus really rose from the dead and belief in life after death. He also reported that $36 \%$ of males agreed that the Bible was irrelevant to life today compared with just $26 \%$ of females. This is reflected in a previous study by Francis (2000: 168) which demonstrated that male teenagers are 
less likely to read the Bible than female teenagers (i.e. $70 \%$ of males said they would never read the Bible compared with $62 \%$ of females). Such a trend is also evident in a study by Harrison (1983) who revealed that reading the Bible is more common among women than men.

Age

The second key influence upon children's attitudes towards the Bible, which the Biblos Project research team investigated, was age. Francis (1986b) has noted clear evidence to suggest that younger pupils have more positive attitudes towards Christianity than older pupils (Glassey, 1943; Davies, 1959; Garrity, 1960; Jones, 1962; Johnson, 1966; Turner, 1970; Povall, 1971; Greer, 1972a; Hinchliffe, 1973; and Francis, 1976). In fact, Francis (1979b: 47) stated that there is a constant and persistent deterioration in children's attitudes towards Christianity according to increase in age. As evidence, he reported that in Year 11 36\% of the pupils judge the Bible to be out of date, compared with $26 \%$ in Year 10 , 26\% in Year 9, 22\% in Year 8 and 17\% in Year 7 (Francis, 1989a: 80-81). In a later study, Francis (2001: 66-7) discussed other significant research which demonstrated similar findings, such as Gibson (1989) and Francis and Greer (1999b). Finally, in his survey of 13-15 year olds, Francis (2001: 72-3) reported a general decline in religious beliefs with age. As evidence he noted that the proportion of pupils who believe that the Bible is irrelevant for life 
today increased from 29\% in Year 9 to 32\% in Year 10. This result is reflected in a previous study by Francis (2000) which found that the Bible is less likely to be read by Year 10 pupils than by Year 9 pupils.

Attendance at a place of worship

The third key influence upon children's attitudes towards the Bible, which the Biblos Project research team investigated, was attendance at a place of worship. Francis (1979a) explained that those who attend church frequently have more positive attitudes towards Christianity than those who do not (Garrity, 1960; Jones, 1962; Hyde, 1965; and Johnson, 1966). Francis (1989a: 82-3) also stated that only $9 \%$ of the weekly churchgoers felt that the Bible is out of date and only $16 \%$ said that they found it boring to listen to the Bible. In terms of the influence of church attendance upon Bible reading, Francis (2000: 169) noted that the Bible is never read by $89 \%$ of boys who claim never to attend church and by $42 \%$ of boys who attend church most weeks. Among girls, the Bible is never read by $84 \%$ of those who never attend church and by $39 \%$ of those who attend church at least once a month. Clearly, the higher the frequency of church attendance, the more likely a pupil is to read the Bible.

Although the key influences upon children's attitudes noted above have been studied in detail before, the third phase of the Biblos 
Project makes an original contribution to knowledge in two main ways. Firstly, the project team decided that it was important to investigate attitudes towards the Bible independently of attitudes towards God, Jesus, prayer, the Church and the Christian instruction and worship offered in schools. The project team did not assume that attitudes towards the Bible were merely one component of a more general attitude towards Christianity. Children's attitudes towards the Bible could be very different from their attitudes towards the Church or Christian instruction and worship in schools. Moreover, the juxtaposition of questionnaire items about the Bible, God, Jesus, prayer, the Church and so forth, which occurred in previous studies, may have affected the way in which pupils interpreted and answered questions about the Bible. Non-Christian pupils, for instance, may accept the social, cultural and moral importance of the Bible, but when it is presented in an exclusively Christian context, their desire to avoid endorsing Christianity as a whole may lead them to respond negatively. For this reason, the Biblos Project had a narrower focus than many of the studies listed above because the Bible, rather than Christianity or religion, was the attitudinal referent. Secondly, the Biblos Project utilised an original psychometric instrument in questionnaire form to generate a new database. The respondents were derived from a broad chronological and geographical sample in that they came from secondary and primary schools in three different areas of England. This is in contrast to Francis' 
quadrennial studies of the attitudes towards Christianity expressed by secondary school pupils in Essex and Sussex only. Therefore, even when the Biblos Project findings replicate those of other studies, the results still provide a helpful contribution to the scientific literature in the field.

\section{Method}

\subsection{Sample}

The sample of questionnaire respondents included 1066 pupils of which 518 were male (48.6\%) and 548 were female (51.4\%). Year 6 pupils accounted for $11 \%$ of the total $(54.7 \%$ male and $45.3 \%$ female). Year 9 pupils accounted for $57.2 \%$ of the total (51.1\% male and $48.9 \%$ female). Finally, Year 12 pupils accounted for $31.8 \%$ of the total (41.9\% male and $58.1 \%$ female). It is important to note that the male/female ratio within each age cohort was relatively even, except for Year 12. The pupil sample also contained pupils with a diversity of religious affiliations: Christianity (70.5\%); None (15.1\%); Sikhism (6.2\%); Hinduism (3.4\%); Islam (2.4\%); Other (1.5\%); Buddhism (0.8\%); and Judaism (0.2\%). The sample was drawn from nine co-educational schools. These do not constitute a base from which generalisations can be made about the whole of the pupil population in England, but they do provide a range of types of school (i.e. primary and secondary; comprehensive and selective; independent, maintained, foundation and voluntary; and 
Church of England, Roman Catholic and community) in different geographical locations (i.e. the North East, South West and Midlands of England) (Copley et al. 2004: 9-10).

\subsection{Questionnaire}

The project began by conducting a pre-pilot study with pupils in Years 6, 9 and 12 from two Devon schools. The main aim was to gather pupils' opinions about the Bible which could then be used to construct attitudinal measures. This was preferred to using statements generated by adult researchers. Firstly, ten pupil opinions about the Bible were presented as items in a five-point Semantic Differential Scale (e.g. 'The Bible is important to me' and 'The Bible is not important to me'). Year 9 and 12 pupils only were asked to tick which statements they 'strongly agreed' or 'agreed' with or whether they were not sure. Secondly, another set of twenty pupil opinions were turned into a five-point Likert Scale for completion by Year 6, 9 and 12 pupils. Pupils were asked to tick one of the following in response to each statement: 'strongly agree', 'agree', 'not sure', 'disagree' and 'strongly disagree'. It was possible to test the validity of our scales by comparing pupils' scores on each scale. The statements in both scales were chosen because they correspond to the words which teachers believe secondary school pupils attribute to the Bible (i.e. boring, oldfashioned, out of date, rubbish, uncool, weird and irrelevant) (Copley, 1997: 56). They also represent the main categories of 
opinion which pupils expressed in response to the KS 4 questionnaire in the second phase of the Biblos Project: veracity; credibility; interest; personal and social relevance; importance; moral influence; and intelligibility (Copley et al, 2001: 27-40). The scales were contained in revised versions of the questionnaires which were piloted in two schools in Dorset. After revision and completion, they were analysed using non-parametric statistical tests in SPSS Version 11.0. The data did not meet the assumptions necessary to undertake parametric tests.

\section{Results}

\section{$\underline{3.1 \text { Attitude Measures }}$}

Firstly, the items for the Semantic Differential Scale and the scale properties, in terms of the alpha coefficients (Cronbach, 1951), are shown in Table 1.

Table 1.

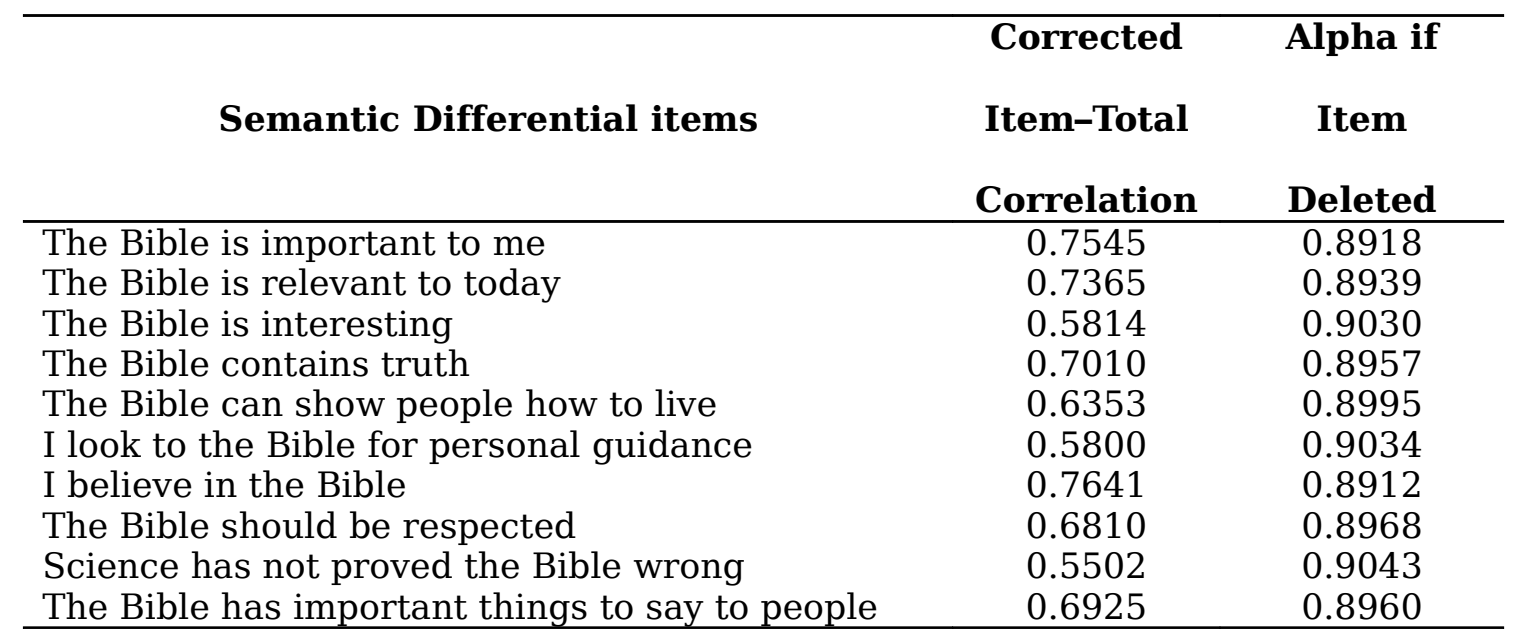


today

Reliability Analysis Cronbach's Alpha $=0.9069$

There was internal consistency amongst responses to the items

within the scale. ${ }^{1}$ Therefore, it was possible to generate a

statistically reliable Semantic Differential Attitude Score (SDAS)

between 10 and 50 for each pupil by adding the item scores

together.

Secondly, the items for the Likert Scale and the scale properties are shown in Table 2.

Table 2 .

\begin{tabular}{|c|c|c|}
\hline Likert Scale items & $\begin{array}{l}\text { Corrected } \\
\text { Item -Total } \\
\text { Correlation }\end{array}$ & $\begin{array}{c}\text { Alpha if Item } \\
\text { Deleted }\end{array}$ \\
\hline The Bible is important because it tells us & 0.6233 & 0.9012 \\
\hline $\begin{array}{l}\text { about God } \\
\text { The Bible is a waste of time } \\
\text { Most of the stories/passages in the Bible are }\end{array}$ & $\begin{array}{l}0.7225 \\
0.6096\end{array}$ & $\begin{array}{l}0.8985 \\
0.9014\end{array}$ \\
\hline $\begin{array}{l}\text { true } \\
\text { The Bible is not important because people no }\end{array}$ & 0.5842 & 0.9022 \\
\hline $\begin{array}{l}\text { longer believe in God } \\
\text { The Bible contains things that in real life }\end{array}$ & 0.5097 & 0.9038 \\
\hline $\begin{array}{l}\text { would not happen } \\
\text { The Bible can help when times are hard } \\
\text { The Bible is not important because it is just a }\end{array}$ & $\begin{array}{l}0.6096 \\
0.6173\end{array}$ & $\begin{array}{l}0.9013 \\
0.9012\end{array}$ \\
\hline $\begin{array}{l}\text { book } \\
\text { The Bible is important but I don't read it } \\
\text { The Bible is the Word of God } \\
\text { The Bible is important if you are religious } \\
\text { The Bible is not important because it is full of }\end{array}$ & $\begin{array}{l}0.0967 \\
0.6432 \\
0.0842 \\
0.6659\end{array}$ & $\begin{array}{l}0.9146 \\
0.9004 \\
0.9143 \\
0.9001\end{array}$ \\
\hline $\begin{array}{l}\text { myths } \\
\text { The Bible is exciting } \\
\text { I would never read the Bible } \\
\text { The Bible is not important because it was }\end{array}$ & $\begin{array}{l}0.6464 \\
0.6991 \\
0.6583\end{array}$ & $\begin{array}{l}0.9002 \\
0.8986 \\
0.9003\end{array}$ \\
\hline
\end{tabular}


written so long ago

The Bible is important for other people but

not for me

The Bible is uncool

not live by it

The Bible is important because it teaches

\section{Reliability Analysis Cronbach's Alpha $=0.9073$}

There was internal consistency amongst responses to the items within the scale. ${ }^{2}$ Therefore, it was possible to generate a statistically reliable Likert Scale Attitude Score (LSAS) between 20 and 100 for each pupil.

It was possible to compare the SDAS and LSAS using Spearman's correlation coefficient (rho). This demonstrated that there was a positive correlation between the two variables that was statistically significant $(\rho=0.87, n=802, p<0.01)$. This makes it possible to use these statistically reliable measures - SDAS and LSAS - to identify which factors are associated with more and less positive attitudes towards the Bible.

The remainder of this article considers the relationship between age, gender, frequency of attendance at a place of worship and the scores which pupils achieved on these measures.

\section{$\underline{3.2 \text { Gender }}$}


The Mann-Whitney U test for statistical significance demonstrated that females were significantly more likely to have a more positive attitude to the Bible than males in terms of the SDAS $(n=846 / 90$, $\mathrm{U}=91578.000, \mathrm{p}<0.05)$. However, there was no statistically significant difference between the attitudes of males and females in terms of the LSAS.

\subsection{Age}

The Kruskal-Wallis statistical test showed that there was a significant difference between the groups of pupils in Year 6, 9 and 12 in terms of the LSAS (Table 6).

Table 6.

\begin{tabular}{cc}
\hline Attitude & LSAS \\
& $\left(\mathrm{n}=936, \mathrm{df}=2, \chi^{2}=16.846, \mathrm{p}<0.01\right)$ \\
\hline Most Positive & Year 6 ${ }^{\text {Year } 12}$ \\
& Year 9 \\
Least Positive & \\
\hline
\end{tabular}

Pupils in Year 6 demonstrate the most positive attitudes towards the Bible and pupils in Year 9 demonstrate the least positive attitudes. This is interesting because $51 \%$ of the Year 6 pupils identified themselves as Christians compared with $72 \%$ in Year 9 and $75 \%$ in Year 12 . This raises questions about the relative importance of religious adherence compared with age in determining pupils' attitudes. Either Christian affiliation produces more negative attitudes towards the Bible or there are more 
significant determinant factors than religious affiliation. There was no statistically significant difference between Year 9 and Year 12 pupils in terms of the SDAS attitude measure.

\subsection{Frequency of attendance at a place of worship}

The pupils were asked how frequently they usually attend a place of worship (e.g. church, synagogue or mosque). ${ }^{3}$ The results were as follows (percentage of total sample in brackets): Sometimes (23.6\%); Rarely (22.8\%); Often (19.1\%); Very Often (18.9\%); and Never (15.5\%). The Spearman rank correlation demonstrated that there was a positive correlation between the frequency with which pupils attend a place of worship and the SDAS $(\rho=0.553, n=897$, $\mathrm{p}<0.01)$ and LSAS $(\rho=0.490, \mathrm{n}=936, \mathrm{p}<0.01)$. Higher frequencies of attendance correlate with more positive attitude scores. This is not surprising because the most common form of religious affiliation in our sample was Christianity and attendance at a Christian place of worship in itself suggests either a generally more positive attitude towards the Bible or exposure to those who have more positive attitudes.

\section{Discussion}

This research suggests that being female, in Year 6 and attending a place of worship very often are factors associated with the most positive attitudes towards the Bible, while being in Year 9, male and never attending a place of worship are associated with the 
least positive attitudes. While it is relatively easy to postulate reasons for the correlation between frequency of attendance at a place of worship and attitudes towards the Bible, one does not know why Year 9 pupils exhibited the least positive attitudes towards the Bible according to the LSAS. Nor does one know why females demonstrated more positive attitudes towards the Bible than males. Levitt (1995: 105) is right to state that psychometric correlation techniques alone cannot 'provide the background knowledge of specific children, the influence of their families, schools, churches and communities which would help to explain the scores they produce'. To achieve this, researchers need to undertake detailed case studies using a combination of in-depth qualitative and quantitative data (Levitt, 1993).

\section{$\underline{4.1 \text { Gender and attitudinal differences }}$}

In terms of the attitudinal differences between the two sexes, Davies (2004: 86) cited five groups of theories about gender differences and religiosity as defined by Kay and Francis (1996). These help to explain the phenomena highlighted above: (i) Sexrole socialisation (i.e. men and women are brought up with distinct ideals and values which make them more or less religious); (ii) Structural-location (i.e. women see themselves as religious role models for their children or their differing role within the workplace provides them with more opportunities to become religious); (iii) Gender-orientation (i.e. feminine and masculine 
orientations of personality, rather than sex, affect religious behaviour) (see Francis and Wilcox, 1996 and 1998); (iv) Depthpsychological (i.e. differing gender responses to God can be explained by differing gender responses to the father figure with females being closer to their fathers than males); and (v) Personality (i.e. personality differences between males and females in areas indirectly related to religion affect religious behaviour, for instance, females are more predisposed to feelings of guilt, frustration, submissiveness and dependency which are answered by religion).

According to Davies (2004: 87), Kay and Francis concluded that sex differences in religiosity are best explained by gender-orientation theories and personality theories. This means that the personality characteristics of masculinity, rather than being male, predispose an individual to more negative attitudes towards religion. For Davies, this has important implications for teacher recruitment. Through his survey of 361 primary school headteachers in Wales, Davies (ibid: 92) demonstrated that female headteachers and male headteachers promote different aims, content and presentation for RE. In conclusion, he suggested that teaching must be made more appealing to people who are characterised by male gender orientation to ensure children have sufficient role models from both sexes and that RE appeals to both gender orientations. Indeed, one may question the extent to which primary schools and secondary 
schools are characterised respectively by females, feminity and religiosity, on the one hand, and males, masculinity and secularity, on the other. One may further speculate what effect these two environments have on the spiritual development of boys and girls, as they get older.

The theories cited above may also help to explain socio-cultural differences between the two sexes which the research team noted (Copley et al. 2004: 19-23). Pupils were asked which hobbies, interests, books, magazines and television programmes they enjoy, and which things matter to them most. By analysing which sex cited which category of answers most frequently, simple generalisations can be made. Males can be described as being interested in 'acts and facts' because they more frequently cited answers pertaining to activities and hobbies (e.g. sport and personal computers) and reading non-fiction literature, especially in magazine format. By contrast, females can be described as being interested in 'human needs and long reads' because they more frequently cited answers pertaining to family, friends and reading books and watching television programmes of a fictional nature. It is understandable which sex would be antipathetic to reading a large book of unproven 'truth' value which is brimming with human issues. 


\subsection{Year group and attitudinal differences}

Francis and Greer (1999a) noted two main theories to explain the decline in attitude towards Christianity with age. The first relates to the use of developmental psychology in RE research. Francis (2000) noted that Goldman (1964) conducted clinical interviews with pupils on three Bible stories to explore how logical thinking develops with age. He analysed their responses according to the Piagetian categories of pre-operational, concrete operational and abstract operational thinking. He concluded that the Bible should not be taught until the transition to formal operational thinking had been achieved because this transition leads to a critical reassessment of immature theology and to a decline in attitude toward Christianity. The second explanation relates to the use of social psychology, such as that of Francis (1989b) and Kay and Francis (1996). The latter associated the decline in attitude with the socialisation process suggesting that as pupils get older they become closer to the world of adult attitudes and values and, since the general attitude toward Christianity in the adult population is relatively low, this becomes the norm to which pupils are drawn (Francis and Greer, 1999a: 176).

The socialisation process was evident in the socio-cultural data which the research team gathered (Copley et al. 2004: 19-23). In general, the older the age group, the more evidence there was of personal and financial independence from the family and a growing 
interest in adult affairs. This was indicated by more frequent citation of: (i) activities such as socialising and a job; (ii) reading genres such as newspapers; (iii) television programmes such as news programmes; and (iv) things that matter most such as friends. In contrast, the younger the age group, the more indication there was of an interest in child-centred media evidenced by more frequent citation of: (i) activities such as PC/games; (ii) reading genres such as comics; (iii) television programmes such as cartoons/animation; and (iv) things that matter to them most such as family. Is the Bible seen as something to be grown out of because it is associated with 'childish' fictional stories and imaginative play, rather than the factual 'real' world of adults? Are positive attitudes towards the Bible connected to higher levels of (familial) dependency?

\section{$\underline{4.3 \text { Interrelationship of variables }}$}

The above correlations are of some use in explaining gender and age differences, but factorial determinants of attitudes are more complex. Differences in the attitude of year groups cannot be understood independently of gender differences, for instance, there was a higher proportion of males than females in the Year 6 sample and yet Year 6 demonstrated the most positive attitudes towards the Bible. This might suggest that age is a more important determinant factor of pupil attitudes than gender. The picture is further complicated by the fact that some of the interests and 
hobbies which were cited more frequently by females than males (i.e. music, socialising, shopping, job and voluntary work) were also cited more frequently by Year 12 s than other year groups. Similarly, the interests and hobbies cited more frequently by Year 6s (i.e. sports and PC/games) were also more frequently cited by males. Therefore, the socio-cultural preferences allocated to different genders above, may in fact be influenced by age. Overall, we need to find more sophisticated ways of controlling for multiple variables and/or adopt the in-depth case study approach advocated by Levitt (1993 and 1995).

\section{Conclusion}

This research presents a challenge to faith communities, RE teachers, textbook writers and Bible publishers to consider how to respond to knowledge about the determinants of young people's attitudes towards the Bible. Because one cannot alter the biblical text and because it is impossible to exclude the factors under review, further research into how to differentiate between different types of pupils is needed. Knowledge of how to transform young people's personal valuations of the Bible will be of interest to the faith communities, but RE teachers may also be interested because prejudicial negative attitudes may preclude high pupil attainment. More generally, knowledge of how to transform young people's social and cultural valuation of the Bible will be of interest to all 
those who recognise the Bible to be a foundational text of western civilisation.

\section{Notes}

1. 169 pupils (15.9\%) provided invalid responses to this question and therefore were coded as missing data.

2. Some pupils provided an invalid response or no response to these statements, but this was never more than $1.9 \%$ of the sample (i.e. 20 pupils).

3. 1 pupil did not identify frequency of worship.

\section{References}

ALVES, C. (1968) Religion and the Secondary School (London: SCM Press).

BOWNESS, C. (2005) Everbody Hurts, Sometimes (Norwich: RMEP/SCM Canterbury Press Ltd).

BRIMICOMBE, M. (2005) Where Are We Going? (Norwich: RMEP/SCM Canterbury Press Ltd).

COPLEY, T. (1998) Echo of Angels: The First Report of the Biblos Project (School of Education, University of Exeter).

COPLEY, T. (2002) Mysterious Encounters (Norwich: RMEP/SCM Canterbury Press Ltd).

COPLEY, C., COPLEY, T., FREATHY, R., LANE, S. \& WALSHE, K. (2004) On the Side of the Angels: The Third Report of the 
Biblos Project (School of Education and Lifelong Learning, University of Exeter).

COPLEY, T., SAVINI, H. \& WALSHE, K. (2002) Biblos Secondary Teacher's Handbook. (Norwich: RMEP/SCM Canterbury Press Ltd).

COPLEY, T., LANE, S., SAVINI, H. \& WALSHE, K. (2001) Where Angels Fear to Tread: The Second Report of the Biblos Project (School of Education and Lifelong Learning, University of Exeter).

COX, E. (1967) Sixth Form Religion: A Report Sponsored by the Christian Education Movement (London: SCM Press Ltd). COX, E. (1971) Changes in attitudes towards Religious Education and the Bible among sixth form boys and girls, British Journal of Educational Psychology, 41, pp. 328-31.

CRONBACH, L. J. (1951) Coefficient alpha and the internal structure of tests. Psychometrika, 16, pp. 296-334.

DAVIES, G. (2004) Gender and attitudes towards religious education in the primary school, British Journal of Religious Education, 26(1), pp. 85-94.

DAVIES, J. A. (1959) A study of the interests and attitudes of pupils at a secondary modern school (Unpublished MA dissertation, University of Wales, Aberystwyth).

FRANCIS, L. J. (1976) An enquiry into the concept 'readiness for religion' (Unpublished Ph.D. dissertation, University of Cambridge). 
FRANCIS, L. J. (1979a) The Child's attitude towards religion: A Review of Research, Educational Research, 21(2), pp. 103-108. FRANCIS, L. J. (1979b) Measurement reapplied: research into the child's attitude towards religion, British Journal of Religious Education, 1(2), pp. 45-51.

FRANCIS, L. J. (1984) Attitude Towards Religion: Definition, Measurement and Evaluation, British Journal of Educational Studies, 32(1), pp. 45-50.

FRANCIS, L. J. (1987) The decline in attitude towards religion among 8-15 year olds, Educational Studies, 13(2), pp.125-134. FRANCIS, L. J. (1989a) Drift from the Churches: Secondary School Pupils' Attitudes toward Christianity, British Journal of Religious Education, 11(2), pp. 76-86.

FRANCIS, L. J. (1989b) Monitoring changing attitudes towards Christianity among secondary school pupils between 1974-1986, British Journal of Educational Psychology, 59, pp. 86-91. FRANCIS, L. J. (1996) Religious Education, in: P. Gordon, P. (Ed) A Guide to Educational Research (London: Woburn Press). FRANCIS, L. J. (2000) Who Reads the Bible? A Study among 13-15 Year Olds, British Journal of Religious Education, 22(3), pp. $165-172$

FRANCIS, L. J. \& GREER, J. E. (1999a) Attitude toward Christianity among Secondary Pupils in Northern Ireland: Persistence of Denominational Differences? British Journal of Religious Education, 21(3), pp. 175-180. 
FRANCIS, L. J. \& GREER, J. E. (1999b) Attitudes towards creationism and evolutionary theory: the debate among secondary pupils attending Catholic and Protestant schools in Northern Ireland, Public Understanding of Science, 8, pp. 93-103. FRANCIS, L. J., PEARSON, P. R. \& LANKSHEAR, D. W. (1990) The relationship between social class and attitude towards Christianity among ten and eleven year old children, Personality and Individual Differences, 11, pp. 1019-27.

FRANCIS, L. J. \& WILCOX, C. (1996) Religion and gender Orientation, Personality and Individual Differences, 20, pp. 119-21.

FRANCIS, L. J. \& WILCOX, C. (1998) Religiosity and Femininity: Do Women Really Hold a More Positive Attitude toward Christianity? Journal for the Scientific Study of Religion, 37, pp. 462-9.

GARRITY, F. D. (1960) A study of the attitude of some secondary modern school pupils towards religious education (Unpublished MEd dissertation, University of Manchester).

GIBSON, H. M. (1989) Attitudes to religion and science among school children aged 11 to 16 years in a Scottish city, Journal of Empirical Theology, 2, pp. 5-26.

GLASSEY, W. (1943) The attitude of grammar school pupils and their parents to education, religion and sport (Unpublished MEd dissertation, University of Manchester). 
GOLDMAN, R. J. (1964) Religious Thinking From Childhood to Adolescence, (London: Routledge and Kegan Paul).

GREELEY, A. (1992) Religion in Britain, Ireland and the USA, in: R. Jowell, L. Brook, G. Prior and B. Taylor (eds) British Social Attitudes: The 9 $^{\text {th }}$ Report (Aldershot: Dartmouth Publishers).

GREER, J. E. (1972a) The attitude of parents and pupils to religion in school, Irish Journal of Education, 4, pp. 39-46.

GREER, J. E. (1972b) A Questioning Generation (Belfast: Church of England Board of Education).

HARRISON, J. (1983) Attitudes to Bible, God, Church (London: Bible Society).

HINCHLIFFE, D. W. (1973) Attitudes to religion, morality and worship of a sample of fifth-form boys and girls (Unpublished DipEd dissertation, University of Birmingham).

HYDE, K. E. (1965) Religious Learning in Adolescence, University of Birmingham Institute of Education Monograph No. 7 (London: Oliver \& Boyd).

HYDE, K. E. (1990) Religion in Childhood and Adolescence: A Comprehensive Review of the Research (Birmingham: AL, Religious Education Press).

JOHNSON, W. P. C. (1966) The religious attitude of secondary county school pupils (Unpublished MEd dissertation, University of Manchester).

JONES, J. A. (1962) An investigation into the response of boys and girls to scripture as a school subject in certain co- 
educational grammar schools in industrial South Wales

(Unpublished MA dissertation, University of Wales, Swansea).

KAY, W. K. (1981) Religious thinking, attitudes and personality amongst secondary pupils in England and Ireland (Unpublished PhD dissertation, University of Reading).

KAY, W. K. \& FRANCIS, L. J. (1996) Drift from the Churches: Attitude toward Christianity during Childhood and Adolescence (Cardiff: University of Wales Press).

LANE, S. (2005). Meetings with Mystery (Norwich: RMEP/SCM Canterbury Press Ltd).

LEVITT, M. (1993) The influence of a Church primary school on children's religious beliefs and practices: a Cornish case study (Unpublished PhD dissertation, University of Exeter).

LEVITT, M. (1995) 'The Church is very important to me': a consideration of the relevance of Francis' 'Attitude Towards Christianity' scale to the aims of Church of England aided schools, British Journal of Religious Education, 17(2), pp. 100-107. POVALL, C. H. (1971) Some factors affecting pupils' attitudes to religious education (Unpublished MEd dissertation, University of Manchester).

ROBERTS, T. N. (1996) It wasn't like that in our day: young people, religion and right and wrong, in: H. Roberts and D. Sachdev (eds) Young People's Social Attitudes: The views of 12-19 year olds (Barkingside: Barnados). 
SAVINI, H. (2002) The Riddle of Destiny (Norwich: RMEP/SCM Canterbury Press Ltd).

TAYLOR, H. P. (1970) A comparative study of the religious attitudes, beliefs and practises of sixth-formers in Anglican, State and Roman Catholic schools and an assessment or religious opinion upon them asserted by home and school (Unpublished MPhil dissertation, University of London).

TURNER, E. B. (1970) Religious understanding and religious attitudes in male urban adolescents (Unpublished $\mathrm{PhD}$ dissertation, The Queen's University of Belfast).

WALSHE, K. (2002) Troubled People (Norwich: RMEP/SCM Canterbury Press Ltd). 